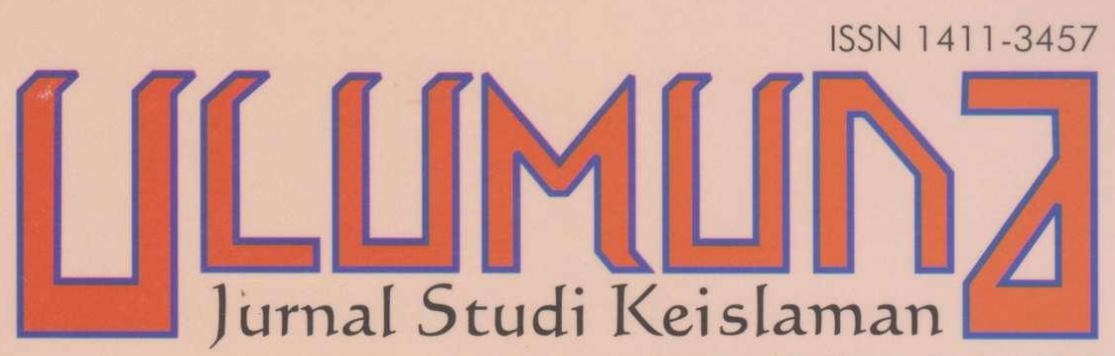

Volume 16 • Nomor 1 • Juni 2012

METOdOLOGI PENEMUAN HUKUM ISLAM Munawir Haris

Pembaruan Metode Penemuan HuKum IsLAm: PENDEKATAN TERPADU HUKUM ISLAM DAN SOSIAL Moh. Lutfi Nurcahyono TIPOLOGI PEMIKIRAN HUKUM ISLAM: PERgULATAN PEMIIIRAN DARI TRADISIONALIS HINGGA LIBERALIS Muhammad Harfin Zuhdi PEMBARUAN MAȘLAHAH DALAM MAQĀSIID AL-SHARĪ'AH: TELAAH HUMANISTIS TENTANG AL-KULLIYYĀT AL-KHAMSAH Zaenuddin Mansyur

MENUJU HUKUM ISLAM YANG INKLUSIF-HUMANISTIS: ANALISIS PEMIIIRAN JASSER AUDA TENTANG MAQĀSITD AL-SHARI'AH Muhammad Salahuddin ARAH PEMBARUAN HUKUM WAKAF INDONESIA Miftahul Huda HUKUM ISLAM DALAM TRADISI LOKAL: TELAAH PEMIKIRAN TGH. M. SOlEH ChAMBALI TENTANG HAJI Adi Fadli PANORAMA POLIGAMI DAN RESISTENSI PEREMPUAN DI LANGSA ACEH Muhammad Ansor PENDEKATAN HUKUM ISLAM TERHADAP JIHAD DAN TERORISME Lukman Arake 



\section{DAFTAR ISI}

\section{Pedoman Transliterasi}

1-20 • Munawir Haris, "Metodologi Penemuan Hukum Islam"

21-40 • Moh. Lutfi Nurcahyono, "Pembaruan Metode Penemuan Hukum Islam: Pendekatan Terpadu Hukum Islam dan Sosial"

41-70 • Muhammad Harfin Zuhdi, "Tipologi Pemikiran Hukum Islam: Pergulatan Pemikiran dari Tradisionalis Hingga Liberalis"

71-102 • Zaenuddin Mansyur, "Pembaruan Maslahahah dalam Maqāṣīd al-Sharī'ah: Telaah Humanistis tentang al-Kulliyyāt al-Khamsah"

103-124• Muhammad Salahuddin,

"Menuju Hukum Islam yang Inklusif-Humanistis:

Analisis Pemikiran Jasser Auda tentang

Maqāṣīd al-Sharī'ah"

125-142 • Miftahul Huda,

"Arah Pembaruan Hukum Wakaf Indonesia"

143-162 • Adi Fadli,

"Hukum Islam dalam Tradisi Lokal:

Telaah Pemikiran TGH. M. Soleh Chambali tentang Haji"

163-188 • Muhammad Ansor,

"Panorama Poligami dan Resistensi Perempuan di Langsa Aceh"

189-222 • Lukman Arake, "Pendekatan Hukum Islam terhadap Jihad dan Terorisme"

LAMPIRAN- LAMPIRAN 


\section{PEDOMAN TRANSLITERASI}

\begin{tabular}{|c|c|c|c|c|c|c|}
\hline 1 & $=$ & $\mathbf{a}$ & & $\dot{\varepsilon}$ & $=$ & $\mathrm{g}$ \\
\hline ب & $=$ & b & & ف & $=$ & f \\
\hline$ت$ & $=$ & $\mathbf{t}$ & & ق & $=$ & $q$ \\
\hline$\dot{H}$ & $=$ & th & & ك & $=$ & $\mathbf{k}$ \\
\hline ج & $=$ & $\mathbf{j}$ & & J & $=$ & 1 \\
\hline$\tau$ & $=$ & ḥ & & s & $=$ & $\mathrm{m}$ \\
\hline$\dot{\tau}$ & $=$ & $\mathbf{k h}$ & & $\dot{ن}$ & $=$ & $\mathbf{n}$ \\
\hline$د$ & $=$ & d & & 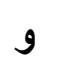 & $=$ & $\mathbf{w}$ \\
\hline$\dot{j}$ & $=$ & dh & & ○ & $=$ & $\mathbf{h}$ \\
\hline$\jmath$ & $=$ & $\mathbf{r}$ & & $\varepsilon$ & $=$ & , \\
\hline j & $=$ & $\mathbf{z}$ & & ي & $=$ & $\mathbf{y}$ \\
\hline س س & $=$ & s & & & & \\
\hline 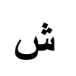 & $=$ & sh & \multicolumn{4}{|c|}{ Untuk Madd dan Diftong } \\
\hline ص - ص & $=$ & ș & i & $=$ & \multicolumn{2}{|c|}{$\bar{a}$ (a panjang) } \\
\hline ض ض & $=$ & d & إي & $=$ & \multicolumn{2}{|c|}{$\overline{1}$ (i panjang) } \\
\hline b & $=$ & $t$ & أو & $=$ & \multicolumn{2}{|c|}{ ù (u panjang) } \\
\hline ظ & $=$ & z & او & $=$ & \multicolumn{2}{|c|}{ aw } \\
\hline$\varepsilon$ & $=$ & 6 & أي & $=$ & \multicolumn{2}{|l|}{ ay } \\
\hline
\end{tabular}

Contoh penulisan dengan transilterasi:

اعوذ بالله من الشيطان الرجيم (a'üdhu bi al-Lāh min al-shaytān al-rajim);

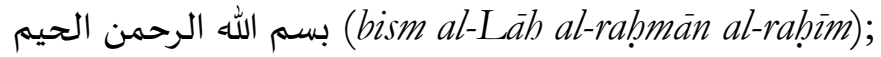

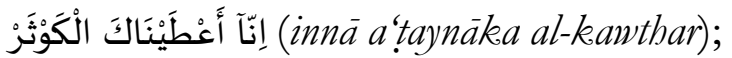

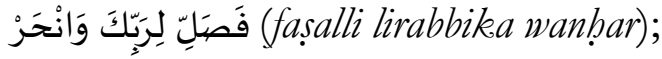

صباح الخير (șabāh al-khayr). 


\title{
TIPOLOGI PEMIKIRAN HUKUM ISLAM: PERGULATAN PEMIKIRAN DARI TRADISIONALIS HINGGA LIBERALIS
}

\author{
Muhammad Harfin Zuhdi \\ (Fakultas Shari`ah IAIN Mataram \\ Email: harfin72@yahoo.co.id)
}

Abstract: Typology of Islamic legal thought is a method to understand the development Islam in the historical reality, and in the context of dynamics and dialectics of interpretation which is strongly associated with the dimensions of space and time. Every Muslim intellectual has its own perspective in understanding the doctrine of his religion, so there are dynamics of struggle of discourse contestation in the Islamic legal thought. This paper aims to elaborate a typology of Islamic legal thought which is categorized into three groups, namely the traditional, moderate, and liberal. The three-categories may represents the struggle of legal thought in the long range of Islamic history.

Abstrak: Tipologi pemikiran bukum Islam merupakan suatu metode untuk memahami Islam yang berkembang dalam realitas sejarah, dan dalam konteks dinamika dan dialektika penafsiran yang sangat terkait dengan dimensi ruang dan waktu. Setiap intelektual Muslim memiliki cara pandang tersendiri dalam memahami doktrin agamanya, maka terdapat dinamika pergulatan wacana kontestasi pemikiran bukum Islam. Tulisan ini bertujuan untuk mengelaborasi suatu tipologi pemikiran bukum Islam yang dikategorikan menjadi tiga kelompok, yaitu tradisional, moderat, dan liberal. Ketiga kategori ini dapat merepresentasikan pergulatan pemikiran hukum dalam rentang panjang sejarah Islam.

Keywords: tipologi, pemikiran hukum Islam, tradisonal, moderat, liberal. 
DALAM panggung sejarah pemikiran hukum Islam, berlangsung proses dialektika tesis, antitesis, dan sintesis ${ }^{1}$ oleh para pemikir dan cendekiawan muslim, sehingga peluang untuk melakukan "kerja keilmuan" terus terbuka bagi mereka yang memenuhi kualifikasi untuk melakukannya. Sebuah pemikiran lahir dari sebuah proses berpikir yang dilatarbelakangi oleh setting sosiopolitik yang melingkupinya. Dalam pendekatan sosio-historis, sebuah pemikiran, gagasan, idea, atau pandangan terhadap suatu gejala atau fenomena yang hidup harus dilihat sebagai sebuah respon intelektual seorang pemikir terhadap fenomena sosial kemasyarakatan dan problem-problem politik yang dihadapinya.

Dengan demikian, sebagaimana pernyataan Amin Abdullah, yang mengatakan bahwa terjadinya suatu perubahan, pergeseran, perbaikan, rethinking process, serta upaya rancang bangun epistemologi keilmuan adalah konsekuensi logis dari kegiatan keilmuan yang memang bersifat historis, karena dibangun berdasarkan akal budi manusia yang juga bersifat historis. ${ }^{2}$

Secara historis, proses dialektika pemikiran Islam mulai tumbuh sejak awal kelahiran Islam pada mana Rasulullah saw.

${ }^{1}$ Dialektika tesis-antitesis-sintesis pertamakali diperkenalkan oleh Hegel. Dalam diskursus Filsafat. Hegel dikenal sebagai tokoh dari "Madhhāb idealisme", lawan dari "madhhāb materialisme" yang diusung Ludwigh Feuerbach. Metode dialektika Hegel dapat dijelaskan secara sederhana yitu: ketika pikiran menangkap fenomena A sebagai sebuah kebenaran sebenarnya di dalamnya terdapat dua unsur, yaitu unsur salah dan unsur benar. Supaya manusia dapat menangkap konsep yang lebih dekat dengan kebenaran maka konsep A harus dihadapkan dengan konsep B. Konsep B merupakan kebalikan dari konsep A sekalipun lahir dari konsep A itu sendiri. Dari pertentangan antara A dengan B tersebut kemudian lahir konsep $C$ yang disebut sintesis. Dengan demikian sintesis merupakan hasil perpaduan antara tesis dengan antitesis. Akan tetapi karena menurut hukum dialektika segala sesuatu senantiasa berkembang dan berubah maka pada gilirannya menempati posisi sebagai tesis yang berhadapan dengan antitesis untuk menghasilkan sintesis yang baru, demikian seterusnya sampai tercapai "kebenaran absolut" yaitu proses dialektika tidak lagi berjalan. Untuk melihat pemikiran Hegel dan pengaruhnya terhadap filosuf setelahnya, lihat misalnya V. Podosetnik dan O. Yakhot, A Brief Course of Dialectical Materialism (Moscow: Progrees Publisher, t.t).

${ }^{2}$ Amin Abdullah, Studi Agama: Normativitas atau Historisitas? (Yogyakarta: Pustaka Pelajar, 1996), 102. 
Kemudian para sahabatnya membangun peradaban Islam yang gemilang, bersanding dengan kekaisaran Romawi yang telah lebih dulu ada, dan bahkan melampauinya. Fakta tersebut terus berlangsung sampai kemudian melahirkan para ilmuwan dan cendekiawan Islam ternama yang bisa dikategorikan sebagai pemikir avantgarde.

Tradisi pemikiran hukum Islam pada masa keemasannya memberikan gambaran yang mengagumkan, di mana pendapat seorang ulama atau cendekiawan tentang suatu masalah dibangun di atas paradigma, kerangka berpikir, atau pun framework tertentu, yang seluruhnya bermuara pada Islamic world view (pandangan hidup Islam). Hal ini menunjukkan bahwa Islam sangat menghargai ijtihād sebagai sebuah proses berpikir yang melahirkan sebuah gagasan besar dalam lapangan ilmu pengetahuan. Dari rangkaian peristiwa sejarah tersebut, sudah seharusnya menginspirasi untuk menumbuhkan keinginan sebagian pemikir dan cendekiawan muslim untuk kembali menghidupkan ruh "pembaruan" Islam, karena merupakan realitas sejarah yang tidak bisa dipungkiri. ${ }^{3}$ Perjuangan dalam rangka mewujudkan "pembaruan" seharusnya tetap berpegang pada "rambu-rambu" yang telah disepakati agar tidak keluar dari koridor yang ada. Hal ini penting untuk diperhatikan, karena jika tidak, akan lahir ide, gagasan, atau produk pemikiran yang tidak sejalan dengan semangat al-Qur'an dan al-Sunnah.

\section{Geneologi Dinamika Pemikiran Hukum Islam}

Secara genealogis, peta pemikiran Islam dapat dilacak sejak awal masa sahabat dengan dua kutub pemikiran yang berkembang, yakni mazhab" ${ }^{4}$ Umari dan 'Alawi. ${ }^{5}$ Mata rantai

3Dalam sebuah hadis yang diriwayatkan oleh Abû Dawud dan lainnya, Rasulullah saw bersabda:

$$
\text { ان الله يبعث لهذه الأمة على رأس كل مائة سنة من يجدد لها دينها }
$$

Artinya "sesungguhnya Allah akan mengutus kepada umat ini setiap akhir seratus tahun sekali orang yang memperbarui agamanya". (HR. Abu Dawud)

${ }^{4}$ Secara etimologis, kata mazhab, berasal dari kata madhhab yang merupakan sigat masdar mim [kata sifat] dan ism makān (kata yang menunjukkan tempat) yang diambil dari fi'il maḍi dhahaba, yang berarti pergi, dan bisa juga berarti al-ra'y, yang berarti pendapat. Jadi madhhab adalah jalan 
mazhab Umari ini dilanjutkan oleh Abdullah bin Mas'ūd. Para tabi'in dari Kufah berguru kepadanya sehingga lahirlah mazhab Kufah yang menitikberatkan fiqh al-ra'yi. Sementara itu, Ali tetap tinggal di Madinah, yang kelak berkembang menjadi mazhab Hijaz yang menekankan fiqh al-athar.

Dengan demikian, polarisasi mazhab fiqh dalam Islam dapat diidentifikasi menjadi dua kelompok besar, yaitu abl al-ra'yu dan abl al-hadith, atau biasa dikenal sebagai faksi Kufah dan faksi Hijaz. Faksi pertama, diwakili oleh imam Abû Hanifah, seorang fäqì dan 'álim yang lebih banyak menggunakan porsi ra'yu, atau paling tidak lebih cenderung rasional dalam pemikiran ijtihadnya. ${ }^{6}$

Sementara faksi kedua, diwakili oleh Imâm Mâlik bin Anas, fäqih dan 'älim yang lebih banyak menggunakan al-hadis dan tradisi masyarakat Madinah sebagai referensi dalam pemikiran ijtihadnya. Sedangkan Imam Syafi'i, dikenal sebagai sintesa antara dua faksi ini, walaupun lebih cenderung kepada abl albadith. Sementara Imam Ahmad bin Hanbal juga dimasukkan dalam faksi abl al-hadith, karena ia seorang mubaddithin, di samping juga sebagai mujtahid mustaqil, di mana pola istinbäthnya lebih dekat kepada metodologi gurunya, Imam Syafi'i. ${ }^{7}$

Selain empat madhhab fiqh yang disebutkan di atas, terdapat sejumlah mazhab fiqh lain, seperti mazhab Zāhiri, Ṭābari, Layth,

pikiran (pendapat) yang ditempuh oleh seorang mujtahid dalam menetapkan hukum Islam yang bersumber dari al-Qur'an dan al-Hadits. Lihat Huzaemah Tahido, Pengantar Perbandingan Mąhab (Jakarta: Logos, 1997), 71. Di samping itu, madhhab juga dipahami dengan school, yang dalam bahasa Arab dipahami sebagai madrasah fikriyah atau madhhab al-'aqli. Jadi, mazhab esensinya adalah aliran pemikiran atau school of thought.

${ }^{5}$ Mazhab 'Umari dinisbahkan dari Umar bin al-Khattâb, sebagai peletak dasar pemikiran rasional dan kontekstual dalam memahami nash. Sementara mazhab 'Alawi terdiri atas sahabat-sahabat yang berkumpul di sekitar Ali bin Abi Thâlib, yang lebih setia kepada teks dengan porsi penggunaan rasio lebih sedikit. Lihat Jalaluddin Rakhmat, Kata Pengantar, dalam Taufik Adnan Amal, Islam dan Tantangan Modernitas: Studi Atas Pemikiran Hukum Fazlur Rabman (Bandung, Mizan, 1993), 18.

'Abu Zahrah, Tarikh al-Mazahib al-Fiqhiyah (Kairo: Mațba' al-Madani, t.th), 188.

${ }^{7}$ Muhammad Ali al-Sayis, Nashah al-Fäqih wa al-Ijtihäd wa atwaruh (Mesir: Majma’ al-Buhus al-Islamiyah, 1970), 10. 
dan sebagainya. Saat ini mazhab-mazhab tersebut kurang berkembang, karena pengikutnya sedikit. Sedangkan di luar kelompok Sunni (abl al-Sunnab wa al-Jamáab) terdapat mazhab Syi'ah, yang terdiri dari dua mazhab besar, yaitu Syi'ah Imamiyah dan Syi'ah Zaidiyah. ${ }^{8}$

Masa inilah yang disebut golden age Islam di segala bidang. ${ }^{9}$ Setelah mengalami fase peak experience (puncak kejayaan) tersebut, umat Islam merasa puas dan hanya menyandarkan diri kepada hasil ijtihad yang dilakukan oleh para mujtahid, sehingga keterikatan kepada mazhab-mazhab fiqh begitu kental dengan sikap fanatisme mazhab. Kondisi ini bermuara pada padamnya semangat ijtihad dan maraknya taklid yang membuat fiqh mengalami kebekuan dan keterpakuan tekstual sehingga menjadi sebuah corpus (kumpulan teks) yang tertutup. Inilah fase stagnasi dan kemunduran peradaban Islam.

Krisis kebekuan berpikir dan kemunduran di segala bidang yang melanda hampir seluruh negeri Islam tersebut melahirkan pemikir dan cendikiawan Islam, seperti Ibnu Taimiyah (w. 278 $\mathrm{H}$ ), yang kemudian diteruskan oleh Ibnu Qoyyim al-Jauziyah (w. $751 \mathrm{H}$ ) dan Al-Syaukani (w. $1834 \mathrm{H}$ ) yang menggelorakan semangat ijtihad dan menentang taklid. ${ }^{10}$

Dalam konteks ini, Fazlur Rahman mengelompokkan gerakan pembaharuan Islam kepada empat bentuk, yaitu 1) Revivalis pra-Modernis; 2) Modernisme Klasik; 3) NeoRevivalisme; dan 4) Neo-Modernisme. ${ }^{11}$

${ }^{8}$ Asmuni Rahman, Ușūl Fiqh Shi'ah Imämiyah (Yogyakarta: Bina Usaha, 1985), 2.

${ }^{9}$ Harun Nasution membagi periodesasi sejarah Islam kepada tiga periode. Pertama, periode klasik $(650-1250 \mathrm{M})$, yang diklasifikasi menjadi dua masa: 1. Masa kemajuan Islam (650 -1000 M); 2. Masa disintegrasi (1000 -1250 M). Kedua, periode pertengahan (1250 - $1800 \mathrm{M})$, yang diklasifikasi menjadi dua masa: 1. Masa kemunduran I (1250 -1500 M); 2. Masa tiga kerajaan besar (1500 - $1800 \mathrm{M})$, yang terdiri dari dua fase: (1) fase kamajuan I (1500 - $1700 \mathrm{M})$; (2) fase kemunduran II (1700 - 1800 M). Ketiga, periode modern (mulai 1800 - sekarang). Lihat Harun Nasution, Islam Ditinjau dari Berbagai Aspeknya (Jakarta: UI Press, 1979), 56-86.

${ }^{10}$ Nasrun Rusli, Konsep Ijtihad al-Syaukani (Jakarta: Logos, 1999), 32.

${ }^{11}$ Fazlur Rahman "Gerakan Pembaharuan dalam Islam di Tengah Tantangan Dewasa ini”, dalam Harun Nasution dan Azyumardi Azra 
Menurut Fazlur Rahman, kelompok pertama muncul pada abad ke-18 yang diwakili oleh Wahabiyah di Saudi Arabia dan Sanusiyah di Afrika Utara. Visi dan misi gerakan tersebut adalah: 1) prihatin terhadap kemerosotan umat Islam; 2) kembali pada Islam yang sesuai dengan tuntunan Nabi Muhammad, membuang takhayul, bid'ah dan khurafât; 3) reinterpretasi terhadap konsep takdir yang salah selama ini; dan 4) perlawanan bersenjata, jika diperlukan. ${ }^{12}$

Pada abad ke-19 muncullah gerakan modernisme klasik yang dimotori oleh Jamaluddin al-Afghani dan Muhammad Abduh. Orientasi gerakan ini adalah perluasan tentang ijtihad terhadap masalah-masalah vital yang dihadapi umat Islam, serta mendorong modernisme klasik agar lebih terbuka terhadap gagasan-gagasan Barat.

Gerakan kedua ini selanjutnya diambil alih oleh gerakan neorevivalisme yang hampir mirip dengan gerakan pertama. Fokus gerakan ini adalah keharaman bunga bank, family planning (keluarga berencana), dan tidak menutup aurat adalah dosa besar. Slogan gerakan neo-revivalise adalah bahwa Islam mencakup seluruh aspek kehidupan. Gerakan ini dimotori oleh Al-Maududi, Khadafi, dan Imam Khumaini. ${ }^{13}$

Pada pertengahan abad XX lahir gerakan neo-modernisme yang dipelopori oleh Fazlur Rahman. Fazlur Rahman mengkritik ketiga gerakan tersebut yang tidak mempunyai metode khusus dalam menangani masalah-masalah yang berkembang dalam dunia Islam. Oleh karena itu, Fazlur Rahman merumuskan metodenya yang terdiri dari tiga langkah, yaitu: 1) pendekatan historis untuk menemukan makna teks al-Qur'an; 2) perbedaan antara ketetapan legal dengan sasaran dan tujuan al-Qur'an; dan 3) pemahaman dan penetapan sasaran al-Qur'an dengan sepenuhnya memperhatikan latar belakang sosiologisnya. ${ }^{14}$

(penyunting), Perkembangan Modern Dalam Islam (Jakarta: Yayasan Obor Indonesia, 1985), 20.

12Ibid., 23.

13Ibid., 26-33.

${ }^{14}$ Muhammad Iqbal, Rekonstruksi Pemikiran Islam: Studi Tentang Kontribusi Gagasan Iqbal Dalam Pembaruan Hukum Islam (Jakarta: Kalam Mulia, 1994), 42. 
Fazlur Rahman dengan pemikiran neo-modernismenya telah merumuskan suatu teori hukum yang disebut sebagai "the double movement theory", yakni dari yang khusus (partikular) ke yang umum (general) dan yang sebaliknya. Gerakan pertama, memahami situasi dan problem historis di mana wahyu diturunkan, kemudian dicarikan rasio-legisnya (illah). Gerakan kedua, menggeneralisasikan dan mensistemasikan prinsip-prinsip umum dari gerakan pertama untuk kemudian dihadapkan pada realitas aktual dewasa ini. ${ }^{15}$

Gagasan neo-modernisme ini berbasiskan sintesis progresif antara rasionalitas modern dan penguasaan khazanah klasik sebagai prasyarat kebangkitan Islam. ${ }^{16}$ Dengan demikian, dapat dikatakan bahwa neo-modernis memiliki concern pada tradisi dan berusaha membangun visi Islam pada masa modern dengan tidak meninggalkan warisan khazanah intelektual Islam. Bahkan jika mungkin, mereka mencari akar-akar Islam untuk mendapatkan kemodernan itu sendiri. Sedangkan kaum "modernis lama" lebih banyak bersifat apologetik terhadap modernitas.

Sementara itu pada aras yang lain, muncul wacana post tradisionalisme Islam. Istilah ini muncul (digunakan) untuk menyebut gerakan yang memiliki ciri-ciri khusus, yang secara kategorial tidak bisa disebut modernis, neo-modernis, dan tidak bisa pula disebut tradisionalis, atau neo-tradisionalis. Istilah ini memang masih debatable, belum memiliki gambaran epistimologi yang jelas. ${ }^{17}$ Namun secara simplistis, gerakan Post-Tradisionalis dapat dipahami sebagai suatu gerakan "lompat tradisi". Gerakan ini, sebagaimana neo-tradisionalis, berangkat dari suatu tradisi yang secara terus menerus berusaha memperbarui tardisi tersebut dengan cara mendialogkan secara intens dengan modernitas, maka akan terjadi sebuah loncatan tradisi dalam kerangka pembentukan tradisi baru (new tradition) yang sama

${ }^{15}$ Rahman, Islam...,48-52.

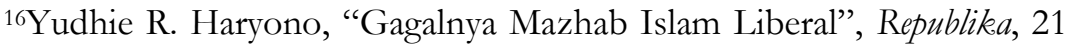
Maret 2001

${ }^{17}$ Marzuki Wahid, "Post Tradisionalis", dalam Pemikiran Islam Kontemporer di Indonesia, ed. Adnan Mahmud, et.al., (Yogyakarta: Pustaka Pelajar, 2005), 84. 
sekali berbeda dengan tradisi sebelumnya. Pada satu sisi memang terdapat kontinuitas, namun pada sisi lainnya banyak bidang yang diskontinuitas dari bangunan tradisi lamanya. Secara umum, bersamaan dengan pengembangan pemikiran PostTradisionalisme terjadi juga nuansa "liberalisasi pemikiran". Fenomena ini terlihat dari kultur hibrida NU (Nahdlatul Ulama).

\section{Tipologi Pemikiran Islam}

Metode berpikir dikotomi-tipologis para sosiolog dianggap sebagai sebuah kecenderungan yang hampir selalu ada pada setiap orang. ${ }^{18}$ Menurut perspektif sosiologis, gambaran tentang sebuah fenomena dari realitas yang dipahami oleh manusia, maka muncul sebuah kecenderungan untuk memetakannya dalam sebuah tipologi-tipologi yang bersifat khusus, tergantung pada kapan dan di mana fenomena itu muncul. Begitu juga dalam ranah pemikiran, hal ini dikarenakan adanya distingsi dari segi pendekatan, metode, framework, dan cara pandang yang dipergunakan oleh setiap pemikir atau pun peneliti dalam melihat obyek penelitian/pemikiran, maka hasil yang diperoleh dari pengamatannya terhadap sebuah obyek menjadi berbedabeda.

Tipologi sendiri merupakan suatu metode untuk memahami pemikiran yang berkembang dalam sejarah, di mana metode ini dianggap obyektif oleh banyak ahli sosiologi karena berisi klasifikasi topik dan tema sesuai dengan tipenya, kemudian dibandingkan dengan topik dan tema yang sama ${ }^{19}$.

Islam sebagai agama samawi yang memiliki kitab suci alQur'an dalam dinamika sejarah mengalami proses dialektika penafsiran yang sangat terkait dengan dimensi ruang dan waktu. Singkatnya, setiap umat Islam (intelektual Muslim) memiliki cara pandang tersendiri dalam memahami doktrin agamanya. Dalam konteks inilah terlihat adanya dinamika pergulatan wacana dalam diskursus pemikiran hukum Islam dengan berbagai varian dalam memahami ajaran Islam.

${ }^{18}$ Fuad Ba'ali dan Ali Wardi, Ibnu Khaldun dan Pola Pemikiran Islam, (Jakarta: Pustaka Firdaus, 1989), 24.

${ }^{19} \mathrm{~A}$. Mukti Ali, "Metodologi Ilmu Agama Islam", dalam Metodologi Penelitian Agama, ed. Taufik Abdullah (Yogyakarta: Tiara Wacana, 2004), 62. 
Secara umum, cara pandang terhadap ajaran Islam dapat dikategorikan ke dalam tiga kelompok, yaitu inklusif, eksklusif dan pluralis. ${ }^{20}$ Kategorisasi seperti ini belum tentu diterima oleh semua kalangan, bahkan sampai saat ini pun setiap kategori yang dipetakan oleh sebagian besar penulis terus mengundang perdebatan. $^{21}$

Dengan demikian tidak menutup kemungkinan munculnya kategori-kategori lain untuk menggambarkan dialektika keragaman pemikiran hukum Islam. Kategori yang dimaksud adalah: Tradisional, Moderat, dan Liberal. Ketiga kategori ini secara umum dapat merepresentasikan pergulatan pemikiran di dunia Islam, termasuk Indonesia. Berikut ini deskripsi dari ketiga kategorisasi di atas:

\section{Tradisional}

Istilah tradisional ketika berdiri sendiri tidak terlalu sulit untuk dipahami, akan tetapi ketika disandingkan dengan kata lain dan menjadi frase, seperti Islam tradisional (traditional Islam), tradisi Islam (Islamic tradition), tradisionalis (traditionalist) atau masyarakat traditional (traditional society), menjadi tidak lagi mudah untuk didefinisikan. Sebagai contoh bagaimana kata traditional menjadi problematis untuk didefinisikan, dimana bisa kita lihat dari perdebatan yang muncul dikalangan sosiolog ketika mengartikan frase traditional society. Traditional society dimaknai sebagai "a non-industrial, predominantly rural society that is presumed to be static and contrasted with a modern, changing, industrial society." Meskipun untuk jangka waktu yang lama, definisi ini

${ }^{20}$ Khamami Zada, "Pemahaman Keagamaan Kelompok Islam Radikal Terhadap Pengembangan Multikulturalisme", Jurnal Istiqra', volume 05 nomor 01 (2006).

${ }^{21}$ Beberapa kajian telah dilakukan oleh intelektual Muslim yang mencoba merumuskan peta pemikiran Islam. Lihat, misalnya, M. Syafi'i Anwar, Pemikiran dan Aksi Islam di Indonesia, (Jakarta: Paramadina, 1995); Bandingkan dengan Syafi'i Ma'arif, Peta Bumi Pemikiran Islam di Indonesia (Jakarta, Paramadina, 1995), 12-3; M. Dawam Rahardjo, Intelektual, Intelegensia, dan Perilaku Politik Bangsa (Bandung: Mizan, 1992), 23-41; Zuly Qodir, "Wajah Islam Liberal di Indonesia: Sebuah Penjajagan Awal", alJami'ah: Journal of Islamic Studies, volume 40 nomor 2 (Juli-Desember, 2002), 334-7.

Llumuna Jurnal Studi Keislaman, Volume 16 Nomor 1 (Juni) 2012 
diterima secara luas oleh kelompok-kelompok yang memiliki kepentingan, namun kemudian menjadi problematis dan kemudian ditolak oleh banyak sosiolog. ${ }^{22}$

Kata tradisi secara etimologis berasal dari kata bahasa Inggris, yaitu tradition. Kata ini diambil dari kata bahasa Latin "traditio" yang bersumber dari kata kerja "tradere"artinya menyampaikan (hand over; deliver). Kata "traditio" sendiri dekat maknanya dengan kata "paradosis" atau kata kerja "paradidõmi" dalam bahasa Yunani yang berarti “menyampaikan". Dengan arti demikian, kata traditio dan paradosis umum digunakan oleh para teolog Kristen Latin dan Yunani untuk menunjukkan sekumpulan ajaran yang dipelihara dan diteruskan oleh Gereja sebagai "keyakinan Katolik" (the Catholic faith).23

Dalam bahasa Arab, istilah "tradisi" biasanya diidentikkan dengan kata sunnah yang secara harfiyah (etimologis) berarti "jalan yang dijalani, terpuji ataupun tidak" (al-sirah, hasanah kānat aw qabiḩah). ${ }^{24}$ Ia juga diartikan sebagai aturan-aturan, cara bertingkah laku, atau tingkah laku kehidupan. ${ }^{25}$

${ }^{22}$ Dalam redaksi aslinya tertulis; the concept is widely used in the social sciences, but over the last few decades has come to be seen as problematic and therefore avoided by many sociologist. Lihat David Jary dan Julia Jary, The HarperCollins Dictionary of Sociology (New York: Harper Collins Publishers, 1991), 525.

${ }^{23}$ Mircea Eliade (ed.), The Encyclopedia of Religion, New York: Simon \& Schuster MacMillan, 1995), Vol. 15, h. 1, artikel: "traditional".

24Ibn Manzuūr, Lisān al-'Arab, jilid 4 (Kairo: Dār al-Hadīth, 2003), 716.

${ }^{25}$ M. M. Azami, On Schacht's Origins of Muhammadan Jurisprudence (Riyadh: King Saud University, 1985), 29. Dalam ranah pemikiran Islam, ada perbedaan pemahaman antara ulama hadis, ulama ushul fiqih, dan ulama fiqih dalam mendefinisikan sunnah. Kalangan ulama hadis lebih menitikberatkan pada sesuatu yang disandarkan kepada Rasulullah SAW dalam kapasitas beliau sebagai Imam yang memberi petunjuk dan penuntun yang memberikan nasehat yang diberitakan oleh Allah swt. sebagai teladan kita. Sehingga mereka mengambil segala sesuatu yang berkenaan dengan Nabi Muhammad saw. baik berupa tingkah laku, postur tubuh, sabda dan perbuatan beliau, baik membawa konsekuensi hukum atau pun tidak. Hal ini sebagaimana definisi yang masyhur menurut mereka; "segala sesuatu yang disandarkan kepada Rasulullah saw. baik perkataan; perbuatan; atau pun berupa taqrì; pengajaran, sifat; kelakuan; perjalanan hidup; baik yang demikian itu sebelum diangkat menjadi Rasul atau sesudahnya”. Sedangkan ulama ușūl membahas segala sesuatu yang datang dari Rasulullah dalam kapasitas beliau sebagai pembentuk shari'at yang menjelaskan kepada 
Dari kata "tradisi" kemudian muncul kata tradisional, tradisionalis dan tradisionalisme. Tradisional artinya menurut adat, turun temurun, atau mengikuti nenek moyang. Sebagaimana yang telah diketahui, istilah ini biasanya dipregunakan untuk menunjuk makna seperti pakaian adat, tarian tradisional, upacara adat, dan seterusnya. Ketiga contoh ini menurut adat terus dipertahankan dan diwariskan secara turun temurun ke generasi selanjutnya. Sementara itu, Istilah "tradisional" banyak dipakai dan digunakan masyarakat sebagai istilah yang digunakan untuk mengimbangi sesuatu yang bercorak atau berbau modern.

Lebih lanjut, istilah "tradisionalist" dengan tambahan "ist" dalam bahasa Inggris umum digunakan untuk menunjukkan orang atau kelompok masyarakat yang dengan gigih serta sungguh-sungguh memegang dan mempertahankan warisan tradisi nenek moyang dan diterapkan dalam kehidupan seharihari. Sebagai contoh Deliar Noer yang mengklasifikasikan kelompok kaum muslimin menjadi dua kelompok, yaitu kelompok kaum tradisionalis dan kelompok kaum modernis. Kolompok tradisionalis seperti Nahḍatul Ulama (NU) dan kelompok modernis seperti Muhammadiyah. ${ }^{26}$ Sedangkan

manusia undang-undang kehidupan, dan meletakkan kaidah-kaidah bagi para mujtahid sepeninggal beliau. Oleh karena itu yang menjadi perhatian mereka adalah sabda, perbuatan, dan taqrì beliau yang membawa konsekuensi hukum dan menetapkannya. Maka sunnah menurut mereka adalah "segala sesuatu yang dinukilkan dari nabi saw., baik perkataan maupun perbuatan atau taqrir yang berkaitan dengan hukum". Sementara itu, ulama fikih membahas segala sesuatu dari Nabi saw. yang berkaitan dengan perbuatan beliau yang bertujuan menunjukkan ketentuan shara' berkenaan dengan perbuatan manusia baik dari segi wajib, haram, mubah, atau yang lain. Maka mereka mendefinisikan sunnah sebagai "suatu perbuatan Rasul saw. yang mengandung shar'i mencakup perbuatan-perbuatan wajib, haram, dan mubah". Lihat Muhammad 'Ajaj al-Khatib, al-Sunnah qobla al-Tadwin (Beirut: Dār al-Fikr, 1981), 16; Muhammad 'Ajaj al-Khātib, Ușūl al-Hadìth: Ulümuh wa Mustalahuh (Beirut: Dār al-Fikr, 1989), 19.

26Deliar Noer, Gerakan Modern Islam di Indonesia 1900-1942 (Jakarta: LP3ES, 1985), 241. Dalam diskursus pemikiran Islam Indonesia saat ini, kategori Deliar Noer nampaknya tidak lagi relevan, karena Muhammadiyah - setidaknya sampai saat ini - cenderung statis dalam arena perdebatan pemikiran Islam. Sementara itu NU yang sering dicap sebagai kaum 
kelompok Jamaah Tabligh oleh Abuddin Nata, dikategorikan juga sebagai kelompok Islam Tradisionalis. ${ }^{27}$

Selanjutnya istilah "tradisonalisme" dengan adanya tambahan akhiran isme tidak lagi bermakna yang menunjukkan sifat atau subyek tertentu (orang/kelompok, tarian, pakaian), melainkan lebih menunjukkan sikap atau kecenderungan seseorang untuk melakukan suatu pekerjaan sesuai dengan tradisi masa lalu atau mengikuti pekerjaan nenek moyang. ${ }^{28}$

Tradisionalisme jika dipadankan dengan makna sikap dan faham tradisional maka dapat melahirkan suatu sikap yang cenderung selalu memegang teguh tradisi warisan masa lalu, biasanya dapat dijumpai pada orang atau masyarakat yang justeru tidak mengenal dengan baik arti warisan masa lalu. Mereka cenderung mengikuti aturan yang sudah baku tersebut tanpa kritis apa maksud dan tujuan yang mereka kerjakan.

Dalam diskursus Islam di Barat, term "tradisi" digunakan untuk menunjuk kelompok Muslim yang dalam hal keagamaan dipandang sebagai kelompok yang selalu berpegang kepada alQur'an dan al-Hadist, kemudian disebut sebagai kaum Islam "literalist tradisional'. Karena kelompok ini memaknai istilah "tradisi" sebagai sunnah, maka mereka menganggap pengikut sunnah adalah kaum tradisionalis yang selalu memecahkan masalah agama dengan al-Qur'an dan hadis serta ketetapan ulama klasik (ijmà).

Istilah tradisionalisme pada akhirnya merupakan lawan dari istilah modernisme yang kemudian melahirkan liberalisme. Masyarakat Barat mendefinisikan modernisme atau modernisasi sebagai fikiran, aliran, gerakan, serta usaha-usaha untuk merubah faham-faham, adat-istiadat, institusi-institusi lama, sesuai dengan

tradisionalis mulai bergerak meninggalkan visi tradisionalnya dan mengarah pada visi Islam yang modern. Hal lain yang cukup mencengangkan adalah bahwa tokoh-tokoh Islam liberal di Indonesia banyak yang merupakan kader-kader muda NU.

${ }^{27}$ Abuddin Nata, Peta Keberagamaan Pemikiran Islam di Indonesia (Jakarta: PT.RajaGrafindo Persada, 2001), 149.

${ }^{28}$ Elizabet K. Notingham, Religion and Society. ter. Abdul Muis Naharong, (Jakarta Rajawali, 1987), 37. 
suasana baru yang ditimbulkan oleh kemajuan ilmu dan teknologi modern. ${ }^{29}$

Dengan demikian, pengertian tradisionalisme dapat dirumuskan sebagai fikiran, gerakan, aliran dan usaha-usaha untuk mempertahankan faham-faham, adat istiadat, institusiinstitusi lama dan sebagainya, meskipun zaman terus berkembang dan maju berkat ilmu dan teknologi. Rumusan ini dapat dikategorikan sesuai dengan arti secara harfiah "tradisionalisme" yaitu kecenderungan atau sikap untuk selalu mempertahankan tradisi warisan sejarah. ${ }^{30}$ Bagi pihak penentang tradisionalisme, sikap menjaga kontinuitas tradisi dan warisan sejarah (heritage) inilah yang pada tahap berikutnya menciptakan ortodoksisme ${ }^{31}$ dalam Islam.

Bedasarkan paparan di atas, maka dapat dirumuskan bahwa tradisionalis adalah kelompok pemikiran yang mempertahankan tradisi-tradisi yang telah mapan. Kelompok ini menegaskan bahwa persoalan umat telah selesai dibicarakan secara tuntas di tangan para pendahulu. Meski demikian, kelompok tradisionalis tidak sama dengan kaum fundamentalis yang sama sekali menolak modernitas, dan membatasi diri hanya kepada Khulafâ al-Râsyidîn. Sedangkan kelompok tradisionalis justeru melebarkan sayapnya kepada Saläf al-Sälih yang tidak menolak pencapaian modernitas, karena apa yang dihasilkan modernitas, sains dan teknologi, bagi mereka tidak lebih dari apa yang

${ }^{29}$ Harun Nasution, Pembaharuan dalam Islam, Sejaran Pemikiran dan Gerakan (Jakarta: Bulan Bintang, 1975), 11

30Pengertian ini sejalan dengan makna tradisionalisme dalam Ensiklopedi Indonesia; yaitu penghargaan yang berlebihan terhadap tradisi dan apa saja yang diberikan masa lampau sejarah (dalam hal ini ilmu, seni, kepercayaan dan adat-istiadat). Tradisionalisme ini yang biasanya mendasari pemikiran yang bersifat konservatif. Lihat Hasan Shadily (pimred), Ensiklopedi Indonesia, Jilid 6 (Jakarta: Ichtiar Baru van Hoeve, tt), 3608.

${ }^{31}$ Dalam pandangan Ruslani: "ortodoksisme biasa dibuat sebagai pelarian atau tempat perlindungan orang-orang skeptis, biasanya para penguasa memanfaatkan sikap seperti ini, karena menguntungkan mereka. Ini disebabkan ortodoksisme lebih mementingkan kelangsungan tradisi, warisan guru dan penjagaan diri kepada hal-hal yang mudharat. Pemikiran bebas tidak mungkin lahir dari ortodoksisme. Ruslani, Masyarakat Kitab dan Dialog Antar Agama: Studi atas Pemikiran Muhammad Arkoun, (Yogyakarta: Yayasan Bintang Budaya, 2000), 71. 
pernah dicapai pada kejayaan Islam dahulu. Dengan demikian mereka masih "mengadopsi" peradaban luar, dengan kriteria semua itu harus diislamkan lebih dahulu. Kecenderungan ini tampak dari upaya mereka melakukan islamisasi segala aspek kehidupan. Termasuk islamisasi ilmu pengetahuan, sebagaimana yang diusung oleh Naquib al-Atas. Menurut Naquib al-Atas, islamisasi ilmu berarti pembebasan ilmu dari penafsiranpenafsiran yang didasarkan pada ideologi sekuler, dimulai dari makna serta ungkapan-ungkapan manusia sekuler. ${ }^{32}$

Kelompok tradisonalis direpresentasikan oleh Husein Nasr, Muthahhari, Naquib al-Atas dan Ismail al-Faruqi. Sedangkan di Indonesia kecendrungan pola pikir seperti ini tampak dalam tradisi pesantren. Contoh Turäth dikalangan pesantren tidak hanya dinilai sebagai sesuatu yang harus dikuti dan ditampilkan kembali dalam kehidupan modern, tetapi telah dianggap sebagai sesuatu yang sempurna. Pemikiran tokoh-tokoh seperti al-Syāfi'i dan al-Ghazâli dianggap telah menyelesaikan berbagai persoalan umat. Hal ini senada dengan apa yang telah diungkapkan Muhammed Arkoun, taqdis al-afkearr al-dini, yaitu sebuah cara berpikir yang oleh Fahmi Huwaidi menyebutnya sebagai penyembahan terhadap teks (ubbädah al-Nușīs). ${ }^{33}$

\section{Moderat}

Secara etimologis, kata "moderat" (moderate [Inggris]) berasal dari bahasa Latin 'moderare' yang artinya "mengurangi atau mengontrol". Dalam The American Heritage Dictionary of the English Language kata moderate didefinisikan sebagai: (1) not excessive or extreme (2) temperate (3) average; mediocre (4) opposed to radical views or measures. (terjemahkan) Sementara itu, dalam Merriam Webster's Unabridged Dictionary, kata moderate memiliki beberapa pengertian; di antaranya (1) characterized by an avoidance of extremes of behaviour (2) Tending to the mean or average (3) not violent or rigorous (4) of or relating to a political or social philosophy or program that avoids extreme measures and violent or partisan tactics.

\footnotetext{
${ }^{32}$ Naquib al-Ațas. Konsep Pendidikan dalam Islam (Bandung: Mizan,1984), 90.

${ }^{33}$ Fahmi Huwaidi, Al-Qur'ān wa al-Sultān Humūm Islämiyah al-Mu'āsirah (Beirut: Dār al-Shurūq, 1982), 41.
} 
Dalam pergulatan pemikiran Islam, kata moderat sering diartikan sebagai "jalan tengah", yaitu tidak berpihak pada salah satu aliran, paham, golongan atau kelompok tertentu. Dengan demikian, apa sebenarnya makna "Islam moderat"? Apakah benar moderat berarti bersikap netral dan tidak berpihak kepada salah satu mainstream?

Muhammad Imarah dalam bukunya Ma'rakah al-Mustalahāt bayna al-Garb wa al-Isläm mengulas terma moderat (al-Wasatiyah) ini dari sudut pandang Islam dan menghadapkannya dengan konsep Barat. Menurut Imarah, dalam konsep Islam, moderat adalah terminologi yang memiliki kandungan makna yang sangat penting dan mulia, namun dalam praktiknya sering disalah artikan. Moderatisme bukan seperti anggapan banyak orang, yaitu tidak ada satu sikap yang jelas dan definitif dalam menghadapi problema serta persoalan-persoalan yang kompleks. Moderat bukanlah jalan pintas atau sikap "plin-plan" dan bingung dalam menentukan pilihan di antara dua sisi yang berseberangan. Moderat dalam Islam bukan semata "sikap ketiga dan baru" tetapi juga adalah sebuah manhäj (metode) yang menengahi dua ekstrimitas yang saling bertentangan, dengan menolak eksageritas (sikap berlebihan) pada salah satu pihak yang pada akhirnya menimbulkan keberpihakan pada salah satu dari dua kutub yang bertentangan. Moderat dalam konsep Islam adalah satu prinsip yang meniscayakan setiap Muslim untuk mampu merangkul dan mengkombinasikan elemen-elemen yang dapat disinergikan dalam satu keharmonisan yang tidak saling memusuhi pada kedua kutub yang berlawanan. ${ }^{34}$

Selanjutnya, dengan meletakkan term wasatiyah dalam konsep Islam, M. Imarah menyatakan bahwa wasatiyah Islam merupakan manhäj yang memadukan antara ruh dan jasad, dunia dan akhirat, agama dan negara, subjek dan objek, yang riil dan ideal, tujuan dan cara, akal dan naql, lokal dan global, ijtihad dan taqlid, agama dan ilmu, yang umum dan yang khusus, yang sakral dengan yang profan, das sein dengan das sollen, dan seterusnya.

${ }^{34}$ Muhammad Imarah, Perang Terminologi Islam Versus Barat, Jakarta: Logos, 1989), 265-267.

Llumuna Jurnal Studi Keislaman, Volume 16 Nomor 1 (Juni) 2012 
Singkatnya, moderatisme Islam melahirkan konvergensi antara dualisme-dualisme yang secara gegabah sering dipertentangkan. ${ }^{35}$ Dalam ranah filsafat hukum Islam, sikap moderat ini tampak dari posisi hukum yang tidak mengenal adanya dikotomi antara positivisme dengan idealisme teori hukum yang digambarkan saling bertentangan. Hukum Islam sebagai hukum yang berdasarkan atas wahyu, mencakup "hukum sebagaimana adanya" dan "hukum sebagai yang seharusnya". Sebagai sebuah hukum, ia adalah perintah Tuhan yang berfungsi sebagai hukum positif, sedangkan sebagai " hukum yang seharusnya" ia adalah ideal karena yang menjadi tujuan akhirnya adalah keadilan. Ini menunjukkan perbedaan antara hukum Islam dengan faham positivisme hukum, khususnya aliran positivisme analitik, yang berkonsentrasi pada analisis konsep-konsep dan hubunganhubungan hukum atas dasar pemisahan yang ketat antara kenyataan (das sein; what is) dengan hal yang seharusnya (das sollen; what should be), dan karenanya ia dipisahkan dari keadilan dan etika. Ia juga berbeda dengan faham idealisme yang lebih didasarkan pada prinsip-prinsip keadilan dan berkaitan dengan "hukum yang seharusnya."36

Di samping itu, sikap moderat sebagaimana dikemukakan oleh Nasaruddin Umar, juga telah dicontohkan oleh Rasulullah saw. dengan memperkenalkan konsep integralisme keilmuan sejati, dengan memadukan secara harmonis antara unsur rasionalitas, unsur moralitas dan seni ke dalam tiga landasan ilmu, yaitu ontologi, epistemologi, dan aksiologi. Rasulullah saw. dinilai telah berhasil meletakkan landasan keilmuan yang integratif antara ilmu-ilmu rasional-analitis dan ilmu-ilmu moralspiritual, sebelum kemudian terjadi pemisahan antara ilmu-ilmu rasional analitik dengan ilmu-ilmu keagamaan pada masa kebangkitan peradaban Barat yang disebut sebagai abad filsafat Yunani II. ${ }^{37}$

35Ibid., 269.

${ }^{36}$ Lihat Fathurrahman Djamil, Filsafat Hukum Islam (Jakarta: Logos Wacana Ilmu, 1999), 62-5.

${ }^{37}$ Nasaruddin Umar, Tradisi dan Pembaharuan Pemikiran dalam Dunia Islam, Makalah yang disampaikan dalam "Konferensi Reformasi Pemikiran dan 
Dari paparan di atas, maka bila kata moderat disandingkan dengan kata Muslim dan membentuk frase "muslim moderat" maka secara sederhana dapat dirumuskan bahwa muslim moderat adalah mereka yang berdiri di antara dua ekstrimitas yang saling berhadapan, tidak memihak pada salah satu kubu, dan berada di garis atau "jalan ketiga" dengan menawarkan solusi yang komprehensif, seimbang, dan adil.

\section{Liberal}

Kata liberal dalam definisi terminologi tetap menjadi perdebatan sampai saat ini, terutama ketika kata liberal dikaitkan dengan kata "Islam", dua entitas yang sesungguhnya bertentangan secara diametral. Frase "Islam liberal" tidak hanya mengandung kontradiksi dalam peristilahan (contradiction in terms) tetapi juga absurd. "Islam" dalam makna generic-nya menuntut kepasrahan, yaitu sikap pasrah seorang hamba kepada Allah dengan mengikuti seluruh perintah dan menjauhi larangan-Nya. Sedangkan kata "liberal", menunjuk pada kebebasan, lepas dari tuntutan dan perintah, dan seterusnya. Oleh karenanya, hampir tidak mungkin untuk mempertemukan dua entitas yang bertentangan ini (Islam dan liberal) menjadi sebuah istilah yang berdiri sendiri. ${ }^{38}$ Pertanyaan yang muncul kemudian adalah bagaimana istilah "Islam liberal" hadir dalam pergulatan

Pendidikan dalam Dunia Islam," Sahid Ballroom, Hotel Sahid Jaya, Jakarta, (10-12 Februari 2006), 2-3.

${ }^{38}$ Dalam sebuah diskusi, Taufik Adnan Amal seraya mendukung Luthfi As-Syakunie (koordinator JIL), mengatakan; "istilah "Islam liberal" tidak perlu didefinisikan. Kalau dibatasi, tentunya tidak liberal lagi. Jadi, maknanya biar berkembang secara liberal di kepala peserta diskusi." Lihat dalam www. Islamlib.com. Pernyataan ini menunjukkan kesulitan kalangan Islam liberal sendiri ketika mereka dihadapkan pada pertanyaan "apa itu Islam liberal?" Meskipun begitu, para pendukung Islam Liberal, khususnya mereka yang terlibat dalam Jaringan Islam Liberal (JIL), dalam situs reminya, menyatakan bahwa Islam Liberal adalah suatu bentuk penafsiran tertentu atas Islam dengan landasan sebagai berikut: 1). Membuka pintu ijtihad pada semua dimensi Islam; 2). Mengutamakan semangat religio etik, bukan makna literal teks; 3). Mempercayai kebenaran yang relatif, terbuka, dan plural; 4). Memihak pada yang minoritas dan tertindas; 5). Meyakini kebebasan beragama dan 6). Memisahkan otoritas duniawi dan ukhrawi, otoritas keagamaan dan politik. 
pemikiran Islam? Dalam kontek itu, apa sesungguhnya makna sebutan "Islam liberal" itu?

Untuk menjawab pertanyaan di atas, ada beberapa referensi sebagai rujukan untuk mengetahui lebih jauh tentang "Islam liberal". Karya Charles Kurzman, Liberal Islam: A Source Book, dan Leonard Binder, Islamic Liberalism, ${ }^{39}$ adalah dua karya yang sering dikutip banyak penulis ketika membicarakan "Islam liberal" dalam konteks global. Namun perlu dicatat bahwa jauh sebelum kemunculan karya Kurzman, Albert Hourani juga telah menggunakan istilah "liberal" dalam karyanya, Arabic Thought in the Liberal Age 1798-1939.40 Selain tiga referensi tersebut, ada juga buah karya A. A. Fyzee - seorang hakim Muslim di Bombay India - berjudul A Modern Approach to Islam, di mana dalam karyanya memperkenalkan istilah "Islam liberal", yaitu terkait dengan upayanya "to understand it (Islam) for today, not as it was in the past, nor as it may be in the future". ${ }^{11}$ Maksudnya, Islam liberal berupaya untuk memahami Islam dalam konteks kekinian, bukan Islam masa lalu, dan bukan pula Islam yang hidup di masa depan. Sementara itu, dalam ranah perdebatan pemikiran Islam di Indonesia, barangkali buku Luthfi As-Syaukanie, Wajah Liberal Islam di Indonesia, JIL, bisa dijadikan referensi.

Di dalam tulisannya, Kurzman tidak memberikan definisi yang akurat tentang istilah Islam Liberal. Ia hanya menyatakan:

Liberal Islam" refers to interpretations of Islam that have a special concern regarding such issues as democracy, separating religion from

${ }^{39}$ Chicago: The University of Chicago Press, 1988.

${ }^{40}$ Cambridge: Cambridge University Press, 1988. Cetakan perdana buku ini adalah tahun 1962 .

${ }^{41}$ A. A. Fyzee, A Modern Approach to Islam, (London: Asia Pub. House, 1963), h. 110. Dalam bukunya Fyzee mengajukan skema penafsiran Islam liberal sebagai berikut: a). Study of History of Religions (Studi Sejarah Agamaagama); b). Comparative Religion of the Semitic Races (Perbandingan Agama dari Ras-ras semit); c). Study of Semitic languages and philology (Studi Bahasa-bahasa Semit dan filologi); d). Separation of Law and Religion (Pemisahan Hukum dan Agama); e). Re-examination of shari'a and kalam (Penjelasan Ulang Terhadap Syariah dan Kalam); f). Reinterpretation of cosmology and scientificfacts (Interpretasi Ulang terhadap Kosmologi dan Fakta-fakta Ilmiah). 
political involvement, women's rights, freedom of thought, and promoting human progress. ${ }^{42}$

Definisi di atas jelas tidak definitif. Kurzman sama sekali tidak memberikan batasan yang jelas yang dapat membedakan Islam Liberal dengan jenis pemikiran Islam yang lain, seperti, modernisme, neo-modernisme, tradisionalisme, posttradisionalisme, atau lainnya. Hal ini pula barangkali yang menyebabkan Kurzman secara gegabah memasukkan intelektual Muslim seperti Yusuf al-Qaradhawi dan M. Natsir kedalam kategori liberal. Sedangkan Leonard Binder mendefinisikan liberalisme dalam konteks Islam:

For Islamic Liberals, the language of the Qur'an is coordinate with the essence of revelation, but the content and meaning of the revelation is not essentially verbal. Since the words of the Qur'an do not exhaust the meaning of revelation, there is a need for an effort beyond them, seeking that which is represented or revealed by language. ${ }^{43}$

Seperti halnya Kurzman, definisi yang diberikan oleh Binder terhadap term Islam liberal juga masih jauh dari rumusan definitif. Jika dijadikan sebagai ukuran liberalisme, inilah yang disebut Binder di atas, maka hampir tidak ada seorang ulama Islam pun yang luput dari kategori liberal, sebab pada kenyataannya dalam upaya penafsiran terhadap ayat-ayat alQur'an, para ulama tidak hanya berpegang pada aspek tekstualitas (harfiyah) al-Qur'an an sich, namun juga melihat makna yang terkandung dibaliknya. Atas dasar itulah mengapa kemudian banyak ditemukan fatwa-fatwa ulama yang melampaui "yang tersurat" (teks).

Kekaburan definisi yang diberikan Kurzman dan Binder di atas menunjukkan bahwa ada upaya untuk memberikan definisi yang dianggap tepat tentang Islam Liberal, maka hasilnya adalah

${ }^{42}$ Charles Kurzman, "Islamic Liberalism: Prospect and Challenges", dalam http:/ / wnw.biu.ac.il/SOC/besa/ meria/journal/1999/issue3/ju3n3a2.html.

${ }^{43}$ Leonard Binder, Islamic Liberalism., 4. Bagi penganut liberalisme Islam, bahasa al-Qur'an berkaitan erat dengan esensi pewahyuan, tetapi isi dan makna dari wahyu itu sendiri tidaklah verbal secara esensial. Karena katakata al-Qur'an tidak menjelaskan secara mendalam makna yang dikandung oleh wahyu, [maka] dibutuhan usaha untuk melampauinya, mencari mana yang direpresentasikan dan mana yang diwahyukan oleh bahasa. 
sebagaimana ungkapan yang mengatakan “jauh panggang dari api."Meskipun sulit untuk mendefinisikannya, namun setidaknya dapat diidentifikasi beberapa kecenderungan yang menjadi identitas atau ciri bagi pemikiran Islam liberal, diantaranya:

Pertama, Islam liberal berangkat dari preposisi bahwa kebenaran adalah relatif, terbuka, dan plural. Maka Islam liberal melakukan dekonstruksi atas "teks", yaitu segala bentuk "teks" dan penafsiran atasnya yang dianggap final. Islam liberal berangkat dari keyakinan bahwa kebenaran tidaklah tunggal. Selalu tersedia ruang untuk melakukan tafsir ulang terhadap seluruh "teks" yang ada, bahkan teks-teks suci (al-Qur'an dan alHadis) sekalipun. Menurut mereka penafsiran tunggal akan mematikan kreativitas akal budi manusia yang semestinya mendapatkan tempat terhormat dalam jagad pemikiran. Paradigma teosentris yang meniscayakan "kewenangan tunggal" Tuhan atas daerah "kebenaran" harus dirubah menjadi paradigma antroposentris di mana manusia menjadi "pusat tafsir" terhadap teks. Karena setiap manusia memiliki kecenderungan untuk melakukan interpretasi atas teks sesuai dengan kondisi psikologis dan sosiologisnya, maka tafsir atas teks itu pun akan beragam pula. Dalam hal ini para pendukung Islam liberal banyak mengadopsi metode dekonstruksi yang diperkenalkan oleh Jacques Derrida - seorang filsuf post-strukturalis asal Perancis -, Levi Strauss, Loran Barthes, dan Michael Foucault yang sejatinya digunakan dalam bidang kritik sastra. Di samping itu, mereka juga gemar menggunakan hermeneutika, baik hermeneutika ala Schleirmacher (1768-1834), William Dilthey (1833-1911) Hans George Gadamer (1900-1998), ${ }^{44}$ Jurgen

${ }^{44}$ Dalam pandangan Gadamer, penafsiran adalah sesuatu yang dijalani, sesuatu yang tidak dapat dikontrol karena praduga-praduga bukanlah milik kita. Praduga-praduga tersebut bukanlah sesuatu seperti yang dapat kita tampilkan seutuhnya. Namun praduga tersebut adalah "kita" bahkan sebelum kita mengetahuinya dan itu adalah pra-syarat positif dari pemahaman dan penafsiran. Gadamer menegaskan praduga adalah sebuah pertimbangan yang dibuat sebelum segala unsur dari sebuah situasi dipastikan (A prejudice is only a judgement made before all the elements of a situation have been ascertained). Praduga bukanlah salah atau benar karena praduga adalah dasar kepada pengetahuan kita. Kita tidak bisa secara serta merta memisahkan antara praduga yang salah dan benar, karena kedua jenis 
Hubermas, Emilio Bety, atau pun yang lain, yang pada prinsipnya sering digunakan dalam metode kritik Bible (Bible Criticism). Sedangkan dari intelektual Muslim, gagasan dari Mohammed Arkoun, Nasr Hamid Abu Zaid, Abdullahi Ahmed An-Na'im, Mohammad Khalafullah, Mahmoud Syahrour dan pemikir lain yang terpengaruh metode dekonstruksi, sering dijadikan rujukan.

Kedua, paralel dengan kecenderungan pertama di atas, Islam liberal menggugat ortodoksi keagamaan yang dianggap mapan dan melakukan dekonstruksi terhadapnya. Dalam berbagai kesempatan, para pendukung Islam liberal sering melontarkan gugatan terhadap pendapat para ulama yang dianggap mapan (established), dan dianggap sebagai "biang kerok" kejumudan Islam. Dari sekian banyak ulama, metodologi yang dibangun oleh Imam as-Syafi'i dan al-Ghazali barangkali yang paling banyak dikritik.

Ketiga, para pendukung kelompok liberal sering menyuarakan "teologi pembebasan", yaitu satu bentuk "teologi" yang menolak segala bentuk penindasan terhadap kebebasan manusia, seperti kebebasan beragama atau kebebasan untuk tidak beragama, dan terutama kebebasan berpikir dan mengeluarkan pendapat. Mereka juga mengklaim berpihak pada kalangan minoritas. Oleh karena itu, dalam kasus-kasus tertentu, seperti tuntutan pembubaran Jama'ah Ahmadiyah oleh mayoritas umat Islam, kalangan liberal berdiri di barisan paling depan untuk membela mereka (Jama'ah Ahmadiyah).

Keempat, kelompok liberal melakukan pemisahan antara otoritas duniawi dan ukhrawi, serta otoritas keagamaan dan politik. Bagi pendukungnya, Agama tidak mempunyai "hak suci" untuk menentukan segala bentuk kebijakan publik. Dalam bidang politik, misalnya, Islam liberal yakin bahwa bentuk negara

praduga tersebut sama-sama membentuk kita. Pemisahan tersebut bisa dilakukan setelah melalui proses proyeksi dan revisi dialogis (Gespräch). Dengan memberi nuansa baru dalam konsep prejudice, Gadamer menolak jika ada teori-teori yang mengklaim berada di atas serta bebas dari prejudice. Lihat Alan How, The Habermas-Gadamer Debate and the Nature of the Social (Avebury: Aldershot, 1995), 44. 
yang sehat bagi kehidupan agama dan politik adalah negara yang memisahkan kedua wewenang tersebut.

\section{Metode Istidlāl Kelompok Liberal}

Kelompok liberal memandang, bahwasanya metodologi istinbät al-hukm yang sekarang berkembang di masyarakat merupakan metodologi yang patut dirubah dengan alasan sebagai berikut:

1. Metodologi klasik terlalu memandang sebelah mata terhadap kemampuan akal publik dalam menganulir ketentuanketentuan legal formalistik dalam Islam yang tidak lagi relevan. Ketika terjadi pertentangan antara akal publik dan bunyi harfiah teks ajaran, metodologi klasik selalu mengalahkan akal publik.

2. Metodologi klasik tidak percaya terhadap kemampuan akal manusia dalam merumuskan konsep maslahat. Manusia tidak memiliki reputasi dan kedudukan dalam ruang usul fikih klasik, kecuali sebagai sasaran hukum.

3. Mensakralkan teks dan pengabaian realitas merupakan ciri umum dari metodologi klasik, kemudian aktivitas ijtihad selalu digerakkan dalam areal teks. Ijtihad yang tidak berakuluminasi pada teks adalah ilegal, sebab teks merupakan aksis dari seluruh cara pemecahan problem. ${ }^{45}$

Paradigma usul fikih klasik menyatakan bahwa sumber hukum pokok (mașādir al-ạsliyah al-asāsiyah) dalam Islam secara hirarki hanya ada empat, yaitu; al-Qur'an, al-hadis, ijma' (konsensus) dan qiyas (analogi). Sementara al-maslahah al-mursalah, istibsān, shar' man qablanā dan 'urf merupakan sumber sekunder atau disebut dengan mașādir al-täbi'iyyah.

Tampak jelas, bahwa al-Qur'an dan al-Sunnah menempati posisi sentral dalam hirarki sumber-sumber hukum dalam Islam. Segala jenis tindakan dan kegiatan harus selalu berada dalam kendali dan kontrol al-Qur'an dan al-Sunnah. ${ }^{46}$

${ }^{45}$ Abdul Muqsith Ghazali, Islam Negara \& Civil Society Gerakan dan Pemikiran Islam Kontemporer (Jakarta: Paramadina, 2005), 352-353.

${ }^{46}$ Muhamad ibn Idrīs al-Shāfīìi, al-Risālah (Mesir: Mushtafa al Halaby. $1940,49$. 
Lepas dari itu, tidak bisa dipungkiri telah terjadi sejumlah paradoks dalam al-Qur'an yang diklaim sebagai poros dari seluruh dalil lain. Paradoks bukan hanya antara satu lafaz dengan lafa yang lain, melainkan juga antara satu gagasan dengan gagasan lain dalam al-Qur'an. Penyelesaian terhadap paradoks lafziyah sudah banyak dilakukan oleh usul fikih klasik. Ketika terjadi ta'ärud antara satu lafaz dengan lafaz lain, maka yang dilihat oleh para mujthid adalah model, karakter dari lafaz, yang membentuk ayat-ayat tersebut. Apakah lafaz ayat itu dikemukakan dengan sigab 'àm, mutlaq atau mujmal? Atau justru dengan menggunakan lafas kehàs, muqayyad, mubayyan dan mansükh. Dari sini, maka dilakukan takhșiss, taquìd, tabyin hingga nasakh. Melalui penanganan laf:ziyyah ini menurut usulfikih klasik, maqāsìd al-sharíah ditemukan. ${ }^{47}$

${ }^{47}$ Istilah maqūsid al-sharīah yang berarti tujuan penetapan hukum ini dipopulerkan oleh seorang ahli ushul fikih dari Madhhāb Malikī, Abū Ishạa al-Shạțịbī, terutama semenjak beredarnya kitab "al-Muwāfaqāt fì usūl alShari"ab", akan tetapi dari sudut gagasan, sebenarnya poin-poin maqạsìd alshari'ah ini sudah pernah dikemukakan oleh ulama uṣul fikih sebelumnya seperti kata al-maqāṣid sendiri menurut Ahmad Raisūni, pertama kali digunakan oleh at-Turmudhī al-Hākim, ulama yang hidup pada abad ke-3. Dialah yang pertama kali menyuarakan Maqāsìd al-Sharīah melalui bukubukunya, al-Salāḥ wa Maqāsiduhū, al-Haj wa Asrāruhū, al-Tllah, 'Tlal al-Sharīah, Tlal al-Ubüdiyyah dan juga bukunya al-Furūq yang kemudian diadopsi oleh alQarāfī menjadi judul buku karangannya. Setelah al-Hākim kemudian muncul Abū Manșūr al-Maturidī (w. 333) dengan karyanya Ma'khad al-Shara' disusul Abū Bakar al-Qaffāl al-Shāshī (w.365) dengan bukunya Ușūl al-Fiqh dan Mạ̣āin al-Sharīah. Setelah al-Qaffāl muncul Abū Bakar al-Abhārī (w.375) dan al-Baqilānī (w. 403) masing-masing dengan karyanya, diantaranya, Mas'alah al-Jawāb wa al-Daläl wa al-'Illah dan al-Taqrīb wa al-Irshäd fì Tartīb Turūq al-Ijtihād. Sepeninggal al- Baqilānī muncullah al-Juwainī dalam kitab alBurhān, al-Gazalī dalam kitab al-Mustasfā, al-Rāzī dalam kitab al-maḥsūl, al'Āmidī dalam kitab al-Iḥkēm, Ibn Ḥājib, al-Bayḍ̄wīi, al-Asnawī, ibn Subukī, ibn 'Abdissalām, al-Qarāfî, al-Ṭ̂ufí, ibn Taimiyyah dan ibn Qayyim. Urutan di atas adalah versi Aḥmad Raisūnī, sedangkan menurut Yūsuf Aḥmad Muhammad al-Badawī, sejarah Maqāsìd al-Sharīah ini dibagi dalam dua fase yaitu fase sebelum ibn Taimiyyah dan fase setelah ibn Taimiyyah. Adapun menurut Hammādī al-Ubaidī orang yang pertama kali membahas Maqāsìd alSharīah adalah Ibrāhīm an-Nakhā̄̄ (w.96H), seorang tabi ìn sekaligus gurunya Hammād ibn Sulaimān gurunya Abū Hanīfah. Setelah itu muncul al-Gazalī, 'Izzuddīn 'Abdussalām, Najmuddīn at-Thūfì dan terakhir alShātịī. Meskipun dengan versi yang beraneka ragam, namun dapat diambil 
Hal yang sangat disayangkan adalah bahwa penanganan terhadap paradoks yang bersifat isu dan gagasan, belum banyak dilakukan oleh ahli dalam usul fikih klasik, seperti gagasan pluralisme agama dalam al-Qur'an. ${ }^{48}$ Oleh karena itu, kelompok liberal menawarkan sebuah gagasan perihal hirarki sumber hukum Islam. Menurut mereka, Maqāsìd al-Sharīah merupakan sumber hukum pertama dalam Islam, baru kemudian diikuti secara beriringan oleh al-Qur'an dan al-Sunnah. Maqāsid alShari'ah merupakan inti dari totalitas ajaran Islam. Maqāsid alShariah menempati posisi lebih tinggi dari ketentuan-ketentuan spesifik al-Qur'an. Maqāșid al-Sharíah merupakan sumber inspirasi tatkala al-Qur'an hendak menanamkan ketentuanketentuan legal spesifik di masyarakat Arab. Maqāsid al-Sharīah adalah sumber dari segala sumber hukum Islam, termasuk sumber dari al-Qur'an itu sendiri. Oleh karena itu, sekiranya terdapat ketentuan dalam al-Qur'an maupun Sunnah yang bertentangan secara subtantif dengan Maqāsid al-Sharíah, maka ketentuan tersebut harus direformasi. Ketentuan tersebut harus dibatalkan demi logika Maqāsìd al-Sharí' ah..$^{49}$

Menurut kelompok liberal, Maqāsid al-Shari'ah tidak hanya digali melalui proses dialektika antara umat Islam dengan teks alQur'an semata, akan tetapi sebagai hasil dari dialog dengan hati nuraninya di satu pihak dan interaksi mereka dengan realitas kehidupan di pihak lain. Berinteraksi dengan relitas, berdiakletika dengan teks suci dan dilanjutkan dengan dialog personal dengan hati nurani secara terus menerus, sehingga akan melahirkan konstruksi Maqāsīd al-Sharīah yang universal. ${ }^{50}$

Oleh sebab itu, kelompok liberal merancang rumusanrumusan usul fikih baru, di antaranya adalah:

\footnotetext{
kesimpulan bahwa sebelum al-Shāṭibī, Maqāsìd al-Sharīah sudah ada dan sudah dikenal, hanya saja susunannya belum sistematis. Lihat bttp:/ / islamlib.com.

48 Abdul Muqsith, Islam .., 356.

${ }^{49}$ Abdul Muqsith, "Metodologi Berfatwa dalam Islam”, dalam http:/ / islamlib.com, diakses 14 Sep. 2003.

${ }^{50}$ Abdul Muqsith, "Membangun Usul Fikih Alternatif", dalam bttp:/ / islamlib.com, diakses 24 Desember 2003.
} 
1. Al-Tbrah bi al-Maqāsìid la bi al-fäz̆ (yang menjadi hukum adalah maksud/tujuan syariat, bukan ungkapannya). Kaidah ini mengandung pengertian bahwa yang menjadi perhatian mujtahid dalam meng-istinbät-kan hukum al-Qur'an dan alSunnah, bukan huruf dan aksaranya melainkan dari maqāsìd yang dikandungnya. Yang menjadi aksis adalah cita-cita etik moral dari sebuah ayat dan bukan legislasi spesifik dan formulasi literalnya. Untuk mengetahui maqāsìd ini, tuntutan tidak hanya mengetahui konteks partikular semata, melainkan juga konteks impersonal yang kulliy. ${ }^{51}$

Kaidah yang diajukan di atas merupakan antipoda dari kaidah klasik yang berbunyi "al-ibrah bi "umümi al-laf:zi la bi khușussi al-sabäb", mengandung arti bahwa harus menjadi pertimbangan dalam menyelesaikan masalah adalah keumuman lafaz bukan khususnya sabāb. ${ }^{52}$ Ini berarti, jika nas menggunakan redaksi yang bersifat umum, maka harus menerapkan nas tersebut, sekalipun nas hadir untuk merespon suatu peristiwa yang khusus.

Kelompok liberal menyatakan, bahwa banyak kritik terhadap kaidah konvensional ini, seperti, Pertama, kaidah ini dipandang terlalu banyak konsentrasi dan bergerak pada medan semantik dengan menepikan peranan sabāb al-nuzūl. Implikasinya adalah para pengguna kaidah ini kerap terjebak pada suatu kenaifan. ${ }^{53}$ Kedua, realitas seharusnya disubordinasikan ke dalam bunyi ḩarfiyah teks. Dalam hal ini yang dituju adalah kebenaran teks dengan konsekwensi mengabaikan konteks (siyāq al-tärikhbi) yang mengitari.

2. Jawāz naskh al-nușuss bi al-mașlaḥah (diperbolehkan menghapus nas dengan kemaslahatan). Sesungguhnya Sharíah al-Islämiyyah

51Al-Gazalī, al-Muștasfā Min 'Ilm al-Uṣūl (Kairo: al-Amiriyah. 1322 H), 26.

${ }^{52}$ Menyangkut kaidah ini, al-Suyûthî memberikan alasan bahwa hal tersebut telah dilakukan oleh sahabat dan golongan lain. Hal Ini bisa dibuktikan, seperti ketika turun ayat żihär dalam masalah Salman ibn Sakhar, ayat li'ân dalam perkara Hilâl ibn Umayyah dan ayat Qadhaf dalam kasus tuduhan terhadap 'Āisyah. Penyelesaian kasus-kasus tersebut dapat diterapkan pada peristiwa lain yang serupa. Lihat Abdurraḥmān al-Suyūṭi, alItqān fì Ulüm al-Qur'ān, (Kairo:T. pn., 1974), 110.

${ }^{53}$ Muqsith, Islam..,359-60. 
tidak memiliki tujuan lain kecuali mewujudkan kemaslahatan kemanusiaan universal (jalb al-masälib) dan menolak kemafsadatan (dar'u al-mafäsid).

Menurut Jaringan Islam Liberal, maslahat memiliki otoritas untuk menganulir ketentuan teks suci. Inilah yang dimaksud dengan ungkapan "naskh al-nususs bi al-maslahah" sebagai spirit dari teks al-Qur'an. Kemaslahatan merupakan amunisi untuk mengontrol balik keberadaan teks dengan menganulir beberapa teks yang sudah tidak relevan dengan kondisi yang ada. Dengan cara ini, cita-cita kemaslahatan akan senantiasa berkreasi untuk memproduksi formulasi teks keagamaan di tengah kegamangan dan kegagapan formulasi teks keagaman klasik. ${ }^{54}$

Teks tersebut bermakna menyertakan kemaslahatan bagi umat manusia. Kemaslahatan yang dimaksud adalah pondasi paling pokok dari setiap perundang-undangan syariat Islam. Ini bukan karena ajaran Islam memang perlu dicocokcocokkan oleh opurtunistik dengan perkembangan kemaslahatan, melainkan karena tuntutan kemaslahatan itu secara obyektif mengharuskan demikian. Menarik mendengar pernyataan 'Izzuddîn ibn 'Abdi al-Salām, "innamà al-taklìf

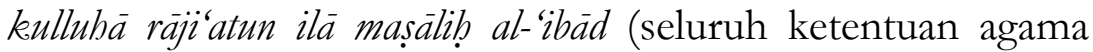
diarahkan seluruhnya untuk kemaslahatan manusia). ${ }^{55}$

3. Tanqî̀ al-Nusūṣ bi al-'Aql al-Mujtama' Yajūzu (diperbolehkan mengoreksi teks dengan akal [pendapat] publik). Kaidah ini meyatakan bahwa akal publik memiliki kewenangan untuk mengamandemen sejumlah ketentun dogmatik agama yang menyangkut perkara-perkara publik dalam al-Qur'an dan alSunnah. Ketika terjadi pertentangan antara akal publik dengan harfiyah teks ajaran, maka akal publik berotoritas untuk mengedit, menyempurnakan, dan memodifikasinya. Modifikasi ini terasa sangat dibutuhkan ketika menghadapi ayat-ayat partikular, seperti ayat 'uqübät, hudüd, qișass, waris dan sebaginya. Hal tersebut menjadi bagian dari masalah yang

${ }^{54}$ Ibid., 362.

55'Izzuddin ibn Abdissalâm, Qawāid al-Aḅkām fì Mașālị̣ al-An'àm, jilid 2 (Beirut: Dār al-Jayl, t.t.), 125. 
harus dipecahkan melalui prosedur tanqīh yang berupa taqyid bi al-'aql, takbssis bi al-'aql dan tabyin bi al-'aql. ${ }^{56}$

Ayat-ayat di atas disebut sebagai fikih al-Qur'an, karena respons al-Qur'an terhadap kasus-kasus tertentu yang berlangsusng dalam kondisi tertentu masyarakat Arab. Dengan demikian, kebenaran ayat-ayat tadi bersifat relatif dan tentatif, sehingga memerlukan penyempurnaan dan pembaharuan. Dalam tataran ini, universalisasi fikih al-Qur'an tanpa melalui proses tanqīh harus dihindari, sebab membiarkan fikih al-Quran persis seperti bunyi harfiyahnya akan mengantarkan al-Qur'an pada perangkap yang mematikan spirit dan elanvital al-Qur'an.

Menurut kelompok liberal, akal publik harus diberi posisi yang penting. Ia tidak cukup hanya diperlukan sebagai pengelola dan alat penafsir seperti teks yang menyangkut perkara-perkara muamalah belaka. Akal publik perlu mendapatkan wewenang untuk mempertanyakan relevansi dan signifikasi ketentuanketentuan spesifik legal al-Qur'an, bahkan sekiranya dari data empiris diketahui secara pasti ketidakberdayaan teks dalam mengatasi perkara-perkara publik, maka akal publik harus mempertimbangkan ulang ketentuan tersebut. Akal publik mempunyai tanggung jawab moral intelektual untuk men-tanqīh ayat-ayat yang cukup problemtik. ${ }^{57}$

\section{Catatan Akhir}

Perdebatan dalam pemikiran hukum Islam tidak lagi terbatas pada ranah furū' tetapi juga merambah pada aspek lain yang sebelumnya telah dianggap final (ma'lüm min al-din al-darürah), hal ini terlihat jelas pada berbagai persoalan kontemporer, misalnya tentang imam dan khatib jum'at perempuan, nikah beda agama, hak waris perempuan, kepemimpinan perempuan dan lain sebagainya.

Para ulama dan cendikiawan muslim kontemporer dalam merespon isu-isu tersebut menampilkan keragaman sikap. Ada yang mengakomodir dan mencoba mengkompromikan, ada pula yang menolak secara tegas, dan juga ada yang menerima tanpa

\footnotetext{
${ }^{56}$ Muqhsith, Islam...,365.

${ }^{57}$ Ibid.
} 
kritik. Polarisasi ulama dan cendikiawan muslim dalam merespon terhadap isu-isu kontemporer tersebut dapat ditemukan hampir di seluruh belahan dunia Muslim, tak terkecuali di Indonesia.

Akhirnya, secara sederhana fragmentasi umat Islam dalam merespon issue-issue yang berkembang dalam diskursus pemikiran kontemporer pun terbagi menjadi tiga kelompok. Pertama, mereka yang secara kukuh tetap berpegang pada basis epistimologi yang telah dibangun oleh para ulama-ulama terdahulu, yakni dalam memahami nash tetap berpegang pada bentuk lahirnya, sehingga terkesan literalis, sekripturalis dan cenderung agak kaku. Kelompok ini memahami syariat itu bersifat absolut, oleh karenanya permanen dan tidak dapat berubah. Kedua, Kelompok yang sedikit banyak telah terpengaruh oleh pemikiran-pemikiran Filsafat Barat, sehingga terkesan Rasionalis, Sekularis, dus Liberalis. Pandanganpandangan kelompok ini bersifat inklusif, dengan mengembangkan pesan-pesan moral seputar keadilan, egalitarianisme, dengan tanpa menonjolkan simbol-simbol keislamaan. Bagi kelompok ini fungsi agama hanya sebagai kekuatan etika dan moral. Berbeda dengan kelompok pertama yang secara kukuh berpegang pada basis epistimologi yang telah dibangun oleh para ulama terdahulu, maka bagi kelompok ini dalam menafsirkan nas lebih berpegang pada substansi atau esensi dari nas tersebut. Mereka menjadikan Asbäb an-Nuzūl dan Asbāb al-Wurüd serta setting social dan setting sejarah sebagai pijakan utama dalam menentukan sebuah hukum.

Ketiga, Corak pemikiran dari kelompok ini adalah mencoba mengkompromikan antara pandangan-pandangan kedua di atas. Atau dengan kata lain pandangan-pandangan kelompok ini adalah merupakan sintesa antara pandangan-pandangan kaum tradisionalis dan liberalis. Dalam hal penafsirannya terhadap nash, kelompok ini sama dengan kelompok liberalis yang berpegang terhadap inti atau isi dari nas, tidak lagi literalis. Oleh karenanya konsep Asbāb an-Nuqūul dan Asbāb al-Wurūd serta setting social dan setting sejarah tetap dijadikan pertimbangan utama. Hanya saja yang membedakan kelompok ini dengan kelompok liberal adalah dalam hal metodologinya. Kalau 
kelompok ini tetap konsisten berpegang pada konsep dasar yang telah dibangun oleh para ulama terdahulu yang kemudian dijadikan metodologi standar sebagai acuan untuk memahami teks baik secara literal maupun kontekstual, misalnya konsep alThawäbit dan al-Mutagayyirat, dan konsep Qat'i dan Zanni. Maka kelompok liberal tidak berpegang terhadap itu semua. Wa al-Lāh Alàm bi al-Ṣawāb.

\section{Daftar Pustaka}

al-Suyūṭị, Abdurraḥmān. 1974. al-Itqān fì Ulüm al-Qứān. Kairo:T. pn.

Ali, A. Mukti. 2004. "Metodologi Ilmu Agama Islam", dalam Taufik Abdullah, ed. Metodologi Penelitian Agama. Yogyakarta: Tiara Wacana.

al-Ghazâlî. 1322. Al-Mushtashfâ Min Tlm al-Ushûl. Kairo: AlAmiriyah.

al-Shātibī. "Maqāsìd al-Shari"ah sudah ada dan sudah dikenal, hanya saja susunannya belum sistematis", dalam bttp:/ / islamlib.com.

Abdullah, Amin. 2002. Studi Agama: Normativitas atau Historisitas. Yogyakarta: Pustaka Pelajar.

Abdissalām, 'Izzuddin Ibn. Qawāid al-Aḅkām fì Masălị̀ al-An'ām. Volume 2. Beirut: Dār al-Jayl, t.t.

al-Khatib, Muhammad 'Ajaj. 1981. al-Sunnah Qobla Tadwin. Beirut: Dār al-Fikr.

al-Shāfíīe Muḥamad ibn Idrīs. 1940. al-Risālah. Mesir: Mushtafa al-Halaby.

Azami, M. M. 1985. On Schacht's Origins of Mubammadan Jurisprudence. Riyadh: King Saud University.

Anwar, M. Syafi'i. 1995. Pemikiran dan Aksi Islam di Indonesia. Jakarta: Paramadina.

Djamil, Fathurrahman. 1999. Filsafat Hukum Islam. Jakarta: Logos Wacana Ilmu.

Eliade, Mircea. 1995. The Encyclopedia of Religion. Volume 15, ed. Simon \& Schuster MacMillan. New York: 1 [Posisi artikel ada pada hlm. 1 dalam ensiklopedi tersebut] 
Ghazali, Abdul Muqsith. 2005. Islam Negara \& Civil Society Gerakan dan Pemikiran Islam Kontemporer. Jakarta: Paramadina. How, Alan. 1995. The Habermas-Gadamer Debate and the Nature of the Social. Avebury: Aldershot.

Imarah, Muhammad. 1989. Perang Terminologi Islam Versus Barat. Jakarta: Logos.

Jary, David dan Jary, Julia. 1991. The Harper Collins Dictionary of Sociology. New York: HarperCollins Publishers.

Mandzur, Ibn. 2003. Lisān al-'Arāb. Kairo: Dār al-Hadith.

Ma'arif, Syafi'i. 1995. Peta Bumi Pemikiran Islam di Indonesia. Jakarta: Paramadina.

Nata, Abuddin. 2001. Peta Keberagamaan Pemikiran Islam Di Indonesia. Jakarta: RajaGrafindo Persada.

Noer, Deliar. 1985. Gerakan Modern Islam Di Indonesia 1900-1942. Jakarta: LP3ES.

Notingham, Elizabet K. 1987. Religion and Society. ter. Abdul Muis Naharong. Jakarta: Rajawali.

Nasution, Harun. 1975. Pembaharuan dalam Islam, Sejarah Pemikiran dan Gerakan. Jakarta: Bulan Bintang.

Qodir, Zuly. 2002. Wajah Islam Liberal di Indonesia: Sebuah Penjajagan Awal", al-Jami'ah: Journal of Islamic Studies, volume 40, nomor 2 (Juli-Desember).

Rahardjo, M. Dawam. 1992. Intelektual, Intelegensia, dan Perilaku Politik Bangsa. Bandung: Mizan.

Ruslani. 2000. Masyarakat Kitab dan Dialog Antar Agama: Studi atas Pemikiran Mubammad Arkoun. Yogyakarta: Yayasan Bintang Budaya.

Shadily, Hasan. Ensiklopedi Indonesia. Jilid 6. Jakarta: Ichtiar Baru Van Hoeve, tt.

Tahido, Huzaemah. 1997. Pengantar Perbandingan Madhbab. Jakarta: Logos.

Yakhot O, dan V. Podosetnik. A Brief Course of Dialectical Materialism. Moscow: Progrees Publisher t.t.

Zada, Khamami. 2006. "Pemahaman Keagamaan Kelompok Islam Radikal Terhadap Pengembangan Multikulturalisme”, Jurnal Istiqra', volume 05, nomor 01. 